\title{
Effect of Residential Property Location on Tenants' Willingness to Pay in Akure, Nigeria
}

\author{
Adedamola F. Audu ${ }^{1}$, Oluwasola S. Adebisi ${ }^{2}$ and Christianah A. Adu ${ }^{2}$ \\ Department of Estate Management, Joseph Ayo Babalola University, Ikeji Arakeji, Osun State Nigeria \\ * E-mail of the corresponding author: afaudu@jabu.edu.ng
}

\begin{abstract}
The study examined the effect of residential property location on tenants' willingness to pay in Akure with a view to providing adequate information that would help in residential property investment decision making in the study area. A structured questionnaire was used in collecting data from the tenants of residential properties within the selected areas. Questionnaires were distributed to Two Hundred and Eighty Two Tenants of residential properties that were selected via simple random sampling method. One hundred and ninety six (196) were retrieved representing $69.50 \%$ of the sample selected. Data collected were analyzed using contingent valuation and binary logistic regression model. Result of data obtained revealed that $57.14 \%$ of the respondents responded positive willingness to pay for residential property location while $42.86 \%$ reported zero willingness to pay for residential property location. The study further showed the bid amount tenants were willing to pay for various improvements in the residential property location, $49.11 \%$ of the respondents are willing to pay between $5-10 \%$ above the current rent for traffic noise reduction. For provision of infrastructure such as good road, electricity and water supply, $30.36 \%$ of the respondents are willing to pay between $5-10 \%$ above the current rent. Factors that influence their willingness to pay for residential location includes length of stay in the property, marital status, age, occupation, income, rent, nearness to place of work, security, electricity supply and water supply amongst others. It was recommended that real estate property owners and developers should consider location critically before embarking on residential property building projects in order to yield optimum returns.
\end{abstract}

Keywords: Residential Properties, Residential Properties Location, Tenants, Willingness to pay.

DOI: $10.7176 / \mathrm{EJBM} / 14-3-03$

Publication date: February $28^{\text {th }} 2022$

\section{Introduction}

Akogun (2011) observed that residential property is a basic necessity of life and its importance is visible in the vital roles it plays in socio-economic and psychological development of individuals, states and nations. Residential properties main purpose is aimed to encompass the shelter and facilities that makes the housing and living environment more meaningful and comfortable for people (United Nations Organisation, 1970). Summarily, humans seek to dwell in residential units that provide the necessary facilities at affordable costs. However, People have concerns about risks or nuisances associated with their environment. These concerns range from worries about health risk to public images of the community, and are rationally related to more than quantitative risk factors (De Vor, F. En H. De Groot, 2009). Therefore, finding a way to avoid such environmental nuisance becomes sacrosanct. One of such is by expressing willingness to pay to avoid the environmental disturbance that constitute nuisance (Fischer, Granger, Fischoff, Nair and Lave, 1991).

Bouvier, Halstead, Conway and Manalo (2000) opined that the question of whether location affects residential property values has long been a subject of debate. Jackson (2002) however found out that there is clear evidence that location (proximity to landmark neighborhood institutions) has an effect on proximate property values. These have been calculated for desirable institutions (such as parks) and its disadvantages such as negative pollution effects from transportation or energy sector installations. Various, concerns have been raised about the possible external effects of location on nature and in particular on households (Needham, 1992; Blaauw, 2007; De Vor, F. and De Groot, H. 2009). This has however prompted the residents and prospective occupants to attempt inferring preferences by their willingness to pay or otherwise. Under conditions of adequate information, the real or perceived location-specific adverse hazard or amenity effects of certain types of land use are, in principle, incorporated in location-related markets as people would be willing to pay to reside where risks or nuisances are lower (Farber, 1998).

In most urban centres, the problem of housing is not only restricted to quantity and the poor quality of available housing units but proximity to various types of other land uses whose disadvantages outweighs the advantages. For instance, while transportation systems clearly enhance neighborhood accessibility, it also negatively affect real estate values by producing noise, pollution, crime, and, in the case of properties located directly in their path, via stigma (De Vor, F. and De Groot, H., 2009). The perceived environmental costs, healthrelated hazards, social and economic impacts associated with these land uses are often confined to the residential properties situated within the immediate zone of influence. Unsuitable residential locations have made the adjoining land use to be perceived as risky because of the inherent negative externalities associated with it (Bouvier. 
2000). Several implications flow from the organisation and operation of activities that have been perceived to be noxious such as Industries, Landfills, G.S.M masts, Transport systems, High tension Wires amongst others (Olukolajo, Ezeokoli and Ogungbenro 2013; Hussain, Gwary, Yusuf and Yusuf, 2017; Vaverkova, Adamcova, Zloch, Radziemska, Berg, Voberkova and Maxianova, 2018; Gaur, Poonams, Ranjna and Mukesh, 2020). Aside from the possible land use compatibility problem that may arise from siting noxious facilities, certain other environmental, social and economic consequences also flow from this. This environmental disamenity could be serious especially in a purely residential setting. These may substantially reduce the standard of living of the local community (De Vor, F. and De Groot, H. 2009). In most instances, the negative externalities outweigh the benefits.

It is pertinent to note that rental values of properties vary from place to place depending on various factors among which facilities availability stand prominent (Small and Steimetz, 2007). Most often, when people talk of the factors affecting rental values of residential properties, the most commonly discussed factors are location, quality of building, demand and supply rate, etc. Little or no regard is given to tenants' willingness to pay for these locations. The study therefore examines the effect of residential property location on tenants' willingness to pay in Akure, Nigeria.

\section{Methodology}

Data for the study was collected through a survey conducted among tenants who were selected through a simple random sampling technique across Akure metropolis (using Odo-Ikoyi, Arakale streets (the CBD), Oluwatuyi/ijoka, Oke Aro/Oshinle, Ijapo and Alagbaka areas of Akure). Binary logistic regression model was used to analyse the factors that influence the tenants' willingness to pay for residential location in Akure. The Binary Logistic Model based on the Contingent Valuation Model was used to calculate the total benefit and explain the socio economic factors influencing tenants willingness to pay for landscaping features (Bello, Audu and Ezeokoli, 2016). Binary logistic regression model is characterized by binary dependent variables with mutually exclusive and exhaustive outcomes. The equation is stated below

$$
\mathrm{WTP}_{i}=\frac{\sum \beta^{\prime} X}{1+\sum \beta^{\prime} X}
$$

Where $\beta^{\prime} X=\alpha+\beta_{1} X_{1}+\beta_{2} X_{2}+\beta_{3} X_{3}+\beta_{4} X_{4}+\beta_{5} X_{5}+\beta_{6} X_{6}+\beta_{7} X_{7}+\beta_{8} X_{8}+\beta_{9} X_{9}+\beta_{10} X_{10}+\beta_{11} X_{11}+\beta_{12} X_{12}+\beta_{13} X_{13}$

$$
+\beta_{14} X_{14}+\mu \ldots \ldots \ldots \text {. (2) }
$$

Where $b_{0}-b_{9}=$ regression coefficient for variables

$\mathrm{X}=$ independent variables

$\mu=$ error term

Table 1: Operationalization of Variables to pay for residential Location

\begin{tabular}{lll}
\hline Variable code & Definition of variable & Measurement scale \\
\hline $\mathrm{X}_{1}$ & Marital status & 1= single, 2=married \\
$\mathrm{X}_{2}$ & Age & Actual in years \\
$\mathrm{X}_{3}$ & Education status & Actual number of years spent \\
$\mathrm{X}_{4}$ & Occupation & $1=$ self employed, $2=$ others \\
$\mathrm{X}_{5}$ & Income & Actual amount \\
$\mathrm{X}_{6}$ & Length of stay in the property & Actual \\
$\mathrm{X}_{7}$ & Rental value & Actual value in Naira \\
$\mathrm{X}_{8}$ & Type of property & Actual \\
$\mathrm{X}_{9}$ & Nearness to the market & 1 (tarred), 0 (otherwise) \\
$\mathrm{X}_{10}$ & Type of road & 1 (tarred), 0 (otherwise) \\
$\mathrm{X}_{11}$ & Nearness to place of work & Actual \\
$\mathrm{X}_{12}$ & Distance from market & Actual \\
$\mathrm{X}_{13}$ & Distance from place of work & Actual \\
$\mathrm{X}_{14}$ & Distance from place of worship & Actual \\
$\mathrm{X}_{15}$ & Road Network & 1 = tarred road, 2 = not tarred \\
$\mathrm{X}_{16}$ & Security & Actual number \\
$\mathrm{X}_{17}$ & Electricity supply & 1(available), 0(other) \\
$\mathrm{X}_{18}$ & Water supply & 1(available), 0(other) \\
$\mathrm{X}_{19}$ & Type of adjoining land use & Actual (type) \\
\hline
\end{tabular}

Source: Author's compilation

Data Analysis and Discussion of findings

This section of the paper deals with analysis of data collected from the study area and the discussion of results. 
Questionnaires were distributed to Two Hundred and Eighty Two Tenants of residential properties that were selected via simple random sampling method. One hundred and ninety six (196) were retrieved and represented $69.50 \%$ of the sample selected. This implied that opinion and inferences drawn from this study was taken from a sizeable percentage. The analysis was structured to include the background information of the respondents, tenants' willingness to pay for residential property location in Akure; and the factors that influence tenants' willingness to pay for residential location in Akure.

Table 2: Background Information on the Respondents and Characteristic of Property occupied (N=196).

\begin{tabular}{lcc}
\hline Distribution & Frequency & Percentage (\%) \\
\hline Sex & & \\
Male & 94 & 48.0 \\
Female & 102 & 52.0 \\
Total & $\mathbf{1 9 6}$ & $\mathbf{1 0 0 . 0}$ \\
\hline & & \\
Age (years) & & 17.9 \\
$20-30$ & 35 & 23.9 \\
$31-40$ & 47 & 37.8 \\
$41-50$ & 74 & 20.4 \\
51 and Above & 40 & $\mathbf{1 0 0 . 0}$ \\
Total & $\mathbf{1 9 6}$ & \\
\hline
\end{tabular}

Highest Level of Education

Primary school certificate

Senior school certificate

33.2

$\mathrm{HND} / \mathrm{BSC}$

$65 \quad 33.2$

$\mathrm{MSc} / \mathrm{PhD}$

Total

Type of property occupied

\begin{tabular}{lcc} 
Brazilian type & 14 & 7.1 \\
Self contain & 27 & 13.8 \\
2 bedroom flat & 32 & 16.3 \\
3 bedroom flat & 75 & 38.3 \\
4 bedroom flat & 44 & 22.5 \\
Duplex & 4 & 2.0 \\
Total & $\mathbf{1 9 6}$ & $\mathbf{1 0 0 . 0}$ \\
\hline
\end{tabular}

$\begin{array}{lcc}\text { Length of stay in the property } & & \\ 1-\quad 5 \text { years } & 68 & 34.7 \\ 6-10 \text { years } & 45 & 23.0 \\ 11-15 \text { years } & 32 & 16.3 \\ 16-20 \text { years } & 51 & 26.0 \\ \text { Total } & \mathbf{1 9 6} & \mathbf{1 0 0 . 0}\end{array}$

Source: field survey, 2021

Table 2 detailed the respondents' demographic characteristic and the characteristic of the property occupied. The sex of the respondents showed that $48 \%$ are male while $52 \%$ are female. This implied that the study cut across both genders. For the age, the age range of 41 and 50 years constituted $37.8 \%$ of the respondents and it is the largest population as shown in the table above. The findings corroborate the findings of Olukolajo, Ogungbenro and Adewusi (2018) that the largest proportion of renters falls between age brackets $41-50$ years. Furthermore, their level of education showed that $53.0 \%$ of the respondents holds a tertiary education certificate. The result therefore revealed that considerable number of respondents are well educated and competent to supply the information that is required for this work and information so supplied could be relied upon.

The type of property occupied as indicated in table 2 above showed that $7.1 \%$ occupied Brazilian type of building, 13.8\% occupied self-contain, $16.3 \%$ occupied 2 bedroom flat, 38.3\% occupied 3 bedroom flat, $22.5 \%$ and $2 \%$ occupied 4 bedroom flat and duplex respectively. The types of property sampled cut across various kinds of residential buildings and this however implies that residential properties prevalent within the study areas are well represented. However Brazilian type of building are the ones that has the least percentage. This could be as a result of the prevalence of this type of building in Akure. From personal observation, a lot of this type of buildings are gradually been converted in order to command a higher rental value. The length of stay indicated that $34.7 \%$ of the respondents have stay in the property between one and five years, $23 \%$ have stayed between six and ten 
years, $16.3 \%$ have stayed between eleven and fifteen years and $26 \%$ have stayed between sixteen and twenty years.

\section{Tenants Willingness to Pay for Residential Property Location in Akure}

This section showed tenants' willingness to pay for residential property location in Akure using contingent valuation model. Surveys were conducted among the tenants occupying properties at the selected areas in order to establish possible differences in the viewpoints and responses of their willingness to pay for locational factors features. The results are however detailed in tables 3, 4 and 5.

Table 3: Descriptive statistics of willingness to pay (WTP) for residential property

\begin{tabular}{lcc}
\hline $\begin{array}{l}\text { Willingness to pay for residential } \\
\text { property location }\end{array}$ & Frequency & Percent (\%) \\
\hline Yes $(\mathrm{WTP}>0)$ & 112 & 57.14 \\
No $(\mathrm{WTP}=0)$ & 84 & 42.86 \\
Total & 196 & 100 \\
\hline
\end{tabular}

Source: field survey, 2021

Table 3 showed the willingness to pay for residential property location in Akure. The questionnaire was designed in a way to carry out test survey and the decision to carry out personal interviews was based on obtaining respondents personal opinion on the subject matter. The first set of questions in the questionnaire was intended to establish and determine the social, economic and demographic characteristics of respondents. Among all the one hundred and ninety six (196) respondents sampled 57. 14\% reported positive willingness to pay for residential property location while $42.86 \%$ reported zero willingness to pay for residential location. The table however implied that larger percentage of the respondent is willing to pay for residential property location.

Table 4: Descriptive statistics of Tenants responses to various contingent questions

\begin{tabular}{lcc}
\hline Questions & \multicolumn{2}{c}{ Frequency (\%) } \\
\hline & $\begin{array}{c}\text { Yes } \\
\text { No (WTP }\end{array}$ & $\begin{array}{c}\text { No } \\
\text { (W) }\end{array}$ \\
\hline $\begin{array}{l}\text { If rent is increased by say 15\% due to improvement in the residential property } \\
\text { location would you still pay for the place you reside? }\end{array}$ & $74(37.76)$ & $122(62.24)$ \\
$\begin{array}{l}\text { Considering your household expenditure, would you pay twice your current rent } \\
\text { for your location to be improved }\end{array}$ & $52(26.53)$ & $144(73.47)$
\end{tabular}

for your location to be improved

Source: field survey, 2021

Table 4 above showed the responses of tenants to various contingent questions being asked in the questionnaire so as to determine their willingness to pay for residential property location. Respondent were asked whether they could pay if their current rent is increased by $15 \%$ due to improvement in the residential property location. $37.76 \%$ replied positive and 62.24 replied negative. Respondents were further asked whether they would pay a sum that was twice the rent they pay considering their household expenditure for their location to be improved and $26.53 \%$ replied positive while $73.47 \%$ replied negative. The reasons given for the negative answers included unaffordability and arbitrary rent amongst others. This therefore implies that the amount the respondents are willing to pay for residential property location differs. The higher the amount gets the lesser the respondents are willing to pay for the location.

Table 5: descriptive statistics of Responses to bid amount tenants were willing to pay $(\mathrm{N}=112)$

\begin{tabular}{|c|c|c|c|c|}
\hline \multirow[t]{2}{*}{ Situations } & \multicolumn{4}{|c|}{ Bid amount (\%) } \\
\hline & $\begin{array}{c}5-10 \% \text { above } \\
\text { current rent }\end{array}$ & $\begin{array}{c}11-15 \% \\
\text { above current } \\
\text { rent }\end{array}$ & $\begin{array}{c}16-20 \% \\
\text { above current } \\
\text { rent }\end{array}$ & $\begin{array}{l}21 \% \text { above } \\
\text { current rent }\end{array}$ \\
\hline traffic noise reduction & $55(49.11)$ & $34(30.36)$ & $11(9.82)$ & $12(10.71)$ \\
\hline Crime rate reduction & $47(41.96)$ & $32(28.57)$ & $20(17.86)$ & $13(11.61)$ \\
\hline Provision of infrastructure such as & $34(30.36)$ & $43(38.39)$ & $15(13.39)$ & $20(17.86)$ \\
\hline
\end{tabular}

good roads, electricity and water

supply

Source: field survey, 2021

Table 5 above showed the bid amount tenants were willing to pay for various improvements in the residential property location. For traffic noise reduction improvement, $49.11 \%$ of the respondents are willing to pay between $5-10 \%$ above the current rent, $30.36 \%$ of the respondents are willing to pay between $11-15 \%$ above the current rent, $9.82 \%$ of the respondents can afford to pay between $16-20 \%$ above the current rent and $10.71 \%$ are willing to pay $21 \%$ and above the current rent. Furthermore, for reduction in crime rate the table also showed that $41.96 \%$ of the respondents are willing to pay between $5-10 \%$ above the current rent, $28.57 \%$ of the respondents are willing to pay between $11-15 \%$ above the current rent, $17.86 \%$ are willing to pay between $16-20 \%$ above the current rent and $11.61 \%$ of the respondents agreed to pay $21 \%$ and above for crime rate reduction. For provision of 
infrastructure such as good road, electricity and water supply, 30.36\% of the respondents are willing to pay between $5-10 \%$ above the current rent, $38.39 \%$ of the respondents are willing to pay between $11-15 \%$ above the current rent, $13.39 \%$ are willing to pay between $16-20 \%$ above the current rent and $17.86 \%$ of the respondents agreed to pay $21 \%$ and above. Due to the negative externalities that traffic noise and crime has on the resident of the urban settings, the residents are willing to pay so that it can be reduced to its barest minimum while residents are willing to pay for Provision of infrastructure such as good roads, electricity and water supply because of its advantages. This therefore implied that respondents are willing to pay more for situations that would make living in a certain location more comfortable and conducive.

Factors that Influences Tenants' Willingness to Pay for Residential Location in Akure.

Tables 6 and 7 detailed the analysis of the factors influencing tenants willing to pay for residential property location in Akure using the binary logistic regression model.

Table 6: Hosmer and Lemeshow Test of Good Fit of the factors influencing Occupiers' willingness to pay for Residential Location in Akure.

\begin{tabular}{lccc}
\hline Step & Chi-square & df & Sig. \\
\hline 1 & 14.552 & 8 & .068 \\
\hline Source: field & & &
\end{tabular}

Source: field survey, 2021

Hosmer-Lemeshow's goodness of fit test statistic as shown in Table 6 above has a significance of 0.068 which means that it is not statistically significant at 0.05 significant level therefore the model is quite a good fit. The $\mathrm{H}$ L statistic assumes sampling adequacy, with a rule of thumb being enough cases so that $95 \%$ of cells (typically, 10 decile groups times 2 outcome categories equals 20 cells) have an expected frequency greater than 0.05 , as expected for well-fitting models. This therefore implies that the model's estimates fit the data at an acceptable level. That is, well-fitting models show non-significance on the Hosmer-Lemeshows goodness of fit test. This desirable outcome of non-significance indicates that the model prediction does not significantly differ from the observed.

Table 7: Variables in the Equation of the factors influencing tenants' willingness to pay for Residential Location in Akure

\begin{tabular}{lcccccc}
\hline & B & S.E. & Wald & df & Sig. & Exp(B) \\
\hline Length of stay & .700 & .556 & 1.584 & 1 & .208 & 2.014 \\
Marital status & .196 & .358 & .299 & 1 & .584 & 1.217 \\
Age & .297 & .336 & .783 & 1 & .376 & 1.346 \\
Education status & -.062 & .430 & .021 & 1 & .885 & .940 \\
Occupation & 1.041 & .398 & 6.852 & 1 & $.009^{*}$ & 2.833 \\
Income & 3.519 & .702 & 25.148 & 1 & $.000^{*}$ & 33.765 \\
Rent & .677 & 1.125 & .362 & 1 & .547 & 1.968 \\
Type of property & -.051 & .948 & .003 & 1 & .957 & .951 \\
Nearness to the market & -.039 & .313 & .015 & 1 & .902 & .962 \\
Type of road network & -.191 & .823 & .054 & 1 & .817 & .826 \\
Nearness to place of work & .091 & .398 & .052 & 1 & .819 & 1.095 \\
Nearness to place of worship & -.092 & .469 & .038 & 1 & .845 & .912 \\
Security & .083 & .331 & .062 & 1 & .803 & 1.086 \\
Electricity supply & .786 & .863 & .831 & 1 & .362 & 2.195 \\
Water supply & .767 & .789 & .947 & 1 & .331 & 2.154 \\
Type of adjoining landuse & -.527 & .311 & 2.882 & 1 & .090 & .590 \\
Constant & -15.550 & 4.620 & 11.328 & 1 & .001 & .000 \\
\hline -2 Log likelihood & 66.918 & & & & & \\
Cox \& Snell R Square & .593 & & & & & \\
Nagelkerke R Square & .834 & & & & &
\end{tabular}

Source: Analysis of field survey, 2021

The model summary detailed in the table above with Cox and Snell's R-Square statistic to be 0.593. This implied that $59.3 \%$ 'likelihood' of the sample variation in tenants' willingness to pay for residential location in Akure is attributed to the independent variables. The Nagelkerke's R-Square which is always higher than the Cox and Snell's R- Square is 0.834 , indicated a strong relationship of $83.4 \%$ between the predictors and the prediction. Table 7 above further showed the factors that determine tenants' willingness to pay for residential locations in Akure. Two variables are statistically significant factor that determines tenants, willingness to pay for residential property location and they include Occupation and income (at 0.05 significant level). The beta value indicates the direction of the relationship between willingness to pay and the dependent variables (which factors increase the likelihood of a yes answer and which factors decrease it). Furthermore, the Exp B values present the extent to which one unit influences the odds ratio when the corresponding measure is been raised or increased. If the value 
exceeds 1 then the odds of an outcome occurring increase; if the figure is less than 1, any increase in the predictor leads to a drop in the odds of the outcome occurring. From the table above, the Exp B value of ten independent variables (length of stay in the property, marital status, age, occupation, income, rent, nearness to place of work, security, electricity supply and water supply) are above 1 . Hence when one of these independent variables are raised by one unit, the odd ratio is the number of times occurring i.e for instance when income level is raised by one unit, the odd ratio is thirty four times as large and therefore income is thirty four times more likely to determine willingness to pay for residential location in Akure. Marital status has 1.217 likelihood of determining willingness to pay for residential location in Akure, age has 1.346 likelihood of determining willingness to pay for residential location, and rent has 1.968 likelihood of determining willingness to pay for residential location. Length of stay in the property has 2.014 likelihood of determining willingness to pay for residential location.

\section{Conclusion and recommendations}

Property assets are a key resource for all types of organizations, including local authorities and public sectors and are fundamental to existence of life. Residential property is considered a basic necessity of life. Decision making in urban or built up areas management and planning requires a formal framework like this to evaluate tenant's willingness to pay for residential property location. The type of apartment people live in and the kinds of facilities made available have implications on the overall gross domestic product of a nation and the environment and require policy response with efforts to improve housing regulations Nigeria. Hence, Real estate property owners and developers should consider location critically before embarking on residential property building projects in order to yield optimum returns. Furthermore, since it was discovered that income and occupation are significant factors that determine willingness to pay, Property managers, Estate Surveyors and Valuers should consider these criteria in tenant selection process in residential properties within Akure Metropolis.

\section{Reference}

Akogun, I.T (2011) A Survey of Infrastructural Facilities and their Effects on Rental Values of Residential Properties in Ilorin Metropolis. Journal of Environmental Sciences and Resource Management vol 3

Bello, V.A, Audu A.F and Ezeokoli, N,B (2016) Tenants' Willingness to Pay for Landscaping Features in Alagbaka Government Reservation Area of Akure, Nigeria. Journal of Sustainable Development Studies 9 (1) $1-16$

Bouvier R.A, Halstead J.M, Conway K.S and Manalo A.B (2000) The Effect of Landfills on Rural Residential Property Values: Some Empirical Evidence. The Journal of Regional Analysis and Policy 130 (2)

Blaauw, K. (2007) Zuinig op Ruimte; Een Provinciale Vergelijking van Bedrijventerreinen. Utrecht:Stichting Natuur en Milieu en de Provinciale Milieufederaties (in Dutch). In De Vor, F. en H. de Groot (2009) Residential Property Values: A Hedonic Pricing Analysis for The Netherlands. Tinbergen Institute Discussion Paper 035 (2)

De Vor, F. and De Groot, H. (2009) The Impact of Industrial Sites on Residential Property Values: A Hedonic Pricing Analysis for the Netherlands. Tinbergen Institute Discussion Paper 035 (2)

Farber, S. (1998) Undesirable Facilities and Property Values: A Summary of Empirical Studies. Ecological Economics 24, 1-14.

Fischer, G.W, Granger, M.M, Fischoff, B, Nair, I and Lave, L.B. (1991). What risks are people concerned about? Risk Analysis Journal 11 (2), $303-314$

Gaur, V.K., Poonam, S., Ranjna, S. and Mukesh, A. (2020) Assessing the Impact of Industrial Waste on Environment and Mitigation strategies: a Comprehensive Review. Journal of hazardous materials 398.123019

Hussain, M.A., Gwary, M.S., Yusuf, I.D. and Yusuf, M.I. (2017) Perception of Effects of GSM Infrastructure on Human Health in Gombe, Nigeria. IOSR Journal of Environmental Science, Toxicology and Food technology $11(7) 44-52$

Jackson, T. (2002). Environmental Contamination and Industrial Real Estate Prices. Journal of Real Estate Research 13(1/2): 179-99

Needham, B. (1992) A Theory of Land Prices when Land is Supplied Publicly: The Case of the Netherlands. Urban Studies, 29, 669-686.

Olukolajo, M.A., Ezeokoli, N.B., and Ogungbenro, M.T. (2013) locational Effect of GSM Mast on Neighbouhood Residential properties rental values in Akure Nigeria. Academic Journal of Interdisciplinary Studies 2(2)

Small, K.A. and Steimetz, S. (2007) Spatial Hedonics and the Willingness to Pay for Residential Amenities. Stanford Environmental Economics Workshop working paper.

United Nations Organisation (1970). Social Programming of Houses in Urban Areas. Publication Series No E71 N10 P3.

Vaverkova, M.D., Adamcova, D., Zloch, J., Radziemska, M., Berg, A.B., Voberkova, S. and Maxianova, A. (2018) Impact of Municipal Solid Waste Landfill on Environment - A Case Study. Journal of Ecological Engineering 19(4) 55-68. 